\title{
Financial Depth, Bank Competition and Economic Performance: A Cross-Country Analysis
}

\author{
Ngonyama Nomasomi ${ }^{1, *}$, Mishi Syden ${ }^{2}$, Sibanda $\mathrm{Kin}^{3}$ and Makhetha-Kosi Palesa ${ }^{4}$ \\ ${ }^{1}$ Economics Department, University of Fort Hare, Alice Campus, 5700, South Africa \\ ${ }^{2}$ Economics Department, Nelson Mandela University, South Africa \\ ${ }^{3}$ Department of Economics, Faculty of Business and Sciences, Nelson Mandela University, Port Elizabeth, \\ South Africa \\ ${ }^{4}$ Economics Department, University of Fort Hare, East London Campus, 5200, South Africa
}

\begin{abstract}
Financial sector development has been receiving a great amount of attention in literature over the years. The finance-growth nexus has been revisited several times with the desire to understand the link between the two as available empirical evidence often fails to explain what is observed in practice. Financial development and sophistication have, in more instances than one, failed to propel growth of economies, with the focus now leaning towards the role of the financial sector structure and competition in this relationship. Making use of cross-country data by applying robust panel data analysis techniques, an analysis of the paradox - the nexus between financial depth, competition and economic performance - was undertaken in the study. The findings have implications for both policy and future research.
\end{abstract}

Keywords: Developing economies, banking sector structure, financial depth, competition, financial inclusion.

\section{INTRODUCTION AND BACKGROUND}

There is significant literature concerning the finance-growth nexus, albeit with diverse conclusions (Durusu-Ciftci, Ispir \& Yetkiner, 2017). Authors who investigated the finance-led growth nexus include, amongst others, Adu, Marbuah, and Tei, (2014); Akinlo and Akinlo (2009); Bernard and Austin (2011); Buffie (1984); Kargbo and Adamu (2010); King and Levine, (1993); Levine and Zervos, (1998); Odedokun, (1996); Schumpeter (1982). Finance is argued to be central to economic growth, facilitating economic activities (Ductor \& Grechyna, 2015; Durusu-Ciftci, et al., 2017), whilst others argue that growth in the economy leads to demand for new and better ways of intermediating between borrowers and savers and the transfer of risk. A notable argument is the one of the emergence of derivatives - it is their development that leads to better way of transacting and doing business, or it is the demand for certain financial securities as the economy grows that facilitates the development of such a class of assets (Hong Vo, Van Huynh, \& Thi-Thieu Ha, 2019). In that regard, Goldsmith (1969); Bernard and Austin (2011); Adu, Marbuah, and Mensah (2013); Akinlo and Akinlo (2009) provided evidence that identifies the significance of development in the financial sector and stated that it leads to economic growth. Furthermore, the studies have identified that

*Address correspondence to this author at the Department of Economics, Faculty of Management and Commerce, University of Fort Hare, 1 King Williams Town Road, Alice, 5700, South Africa; Tel: +27 40602 2481;

E-mail: NNgonyama@ufh.ac.za there is a positive unidirectional causality, where finance leads to economic growth.

Despite overwhelming evidence showing that there is a significant positive relationship between the variables, meaning that financial sector development leads to economic growth, Adu, Marbuah, and Mensah (2013) found a negative link between financial sector development and economic growth. This latter finding argued that the financial sector to some extent is considerably relative in size, whereby financial intermediaries (banks) are contributing relatively to lower economic growth (Gambacorta, Yang \& Tsatsaronis, 2014). There are studies, on the other hand, that do not show any significant link between economic growth and financial sector development (Andersen \& Tarp, 2003). In essence, finance is essentially irrelevant to (or independent of) growth. This is in accordance with Mahonye and Ojah (2014), who concluded that growth is not necessary even in the financial structure.

In terms of development and complexity, various economies hold top rankings in financial systems, but growth is deceiving (Gambacorta, Yang \& Tsatsaronis, 2014). The situation culminated in the debate on whether the financial system is geared towards capital markets or the banking sector is concerned with the political-economic growth relationship. This debate has different findings regarding the relationship of financial development to economic growth, as opposed to the market-based economy (e.g. South Africa; United 
States of America). Gorg, Krieger-Boden, Moran, and Seric (2017) echoed that economic development depends mainly on the local financial system.

Three findings arise from literature: the role in economic growth of both financial markets and of financial intermediaries (Boyd, Levine, \& Smith, 2001; Levine and Zervos, (1998); the structure of the financial system is not important and matters not; (Levine, 2002); the response to the complexity of the relationship is derived from the fact that the level of economic and financial growth of a nation differs (Demirgüç-Kunt et al., 2011). The first hypothesis appears unquestionable and the second conclusion is questioned by the different levels of financial innovations and growth that occur in reality. The financial system needs to balance between banks and markets in a capital budgeting process. Literature says, however, that, at an earlier development phase, countries have a market-based and bank-based financial system providing intermediary services (Demirgüç-Kunt et al., 2011; Gamacorta, Yang \& Tsatsaronis, 2014).

Based on the third finding, the debate therefore needs to incorporate the features of financial development, such as financial depth and sector competition. In practice, it has been noted that economies with robust financial development have not always enjoyed great and inclusive growth, with South Africa being an example of having a deep financial system and poor economic growth compared to Europe, Canada, and Australia (Gambacorta, et al., 2014).

Financial depth is defined as the access, usage and quality or relevance of the financial product and/or service and it is split into two, namely banking system depth and market system depth (Nyantakyi \& Sy, 2015). This structuring also reflects two broad categories of financial systems - bank-based versus capital (market)-based. Financial depth, on the other hand, market structure and conduct of entities within the sector need to be considered, as all these determine the extent of the contribution finance can make to the growth of the economy (Claessens \& Laeven 2005; Fernández de Guevara \& Maudos 2011; Gaffeo \& Mazzocchi, 2014; Mitchener \& Wheelock, 2013).

On the same note, the degree to which competition amongst financial institutions has played a significant role in determining the rate at which financial sector development influences economic growth is worth investigating. There is scant literature that relates to this relationship and it is further narrowed to the relationship between market-based vs bank-based effect on economic growth. The intensification of competition and financial innovation in markets is reasoned to significantly contribute to the implications of financial sector development on economic growth. Loayza and Ranciere (2004) once noted the establishment of unrestrained and unchecked instruments by banks with the motive of countering competition, causing macro-economic instabilities which in turn may impact growth negatively. However, in most studies, competition amongst banks and other institutions has not been econometrically tested as an interaction variable influencing the finance-growth nexus. Very few studies have combined financial development and competition on the same model measuring how they impact economic growth.

The level of competition amongst firms has been measured by concentration indicators, where higher concentration means low competition (Mirkin, Kuznetsova \& Kuznetsov, 2013). The use of concentration indicators as proxies of competition received much criticism as banks continue to be competitive due to easy entry and exit caused by market liberalisation (Beck, 2008; Boone, 2001; Panzar, \& Rosse, 1987; Leon, 2014). The criticism gave rise to direct measures of competition from the pricing behaviour and or market power. Such measures include the Panzar-Rosse $\mathrm{H}$-statistic, the Lerner index, and the Boone indicator (Beck, 2008; Boone, 2001; Panzar, \& Rosse, 1987; Leon, 2014). This study has taken note of the development in measures of competition to advance literature.

The study sought to explore the relationship between financial depth, competition and economic performance. Incorporating bank competition is crucial and of great significance because most financial crises are linked to financial sector entities trying to outplay others through use of innovative, sophisticated or obscure financial products. Competition amongst banks is also traced to globalisation, that is financial openness of financial institutions and markets which has led to an unhealthy degree of competition in the financial sector.

Investigating this nexus advances literature from the current standing in the following important ways: bringing the three variables together to understand finance-growth relationship; making use of a large data 
set - 64 developing and emerging economies - and avoiding distortion from mixing developed and developing economies; and use of financial development index and dependent variable being either development or growth. Following this introduction and background; section 2 deals with the literature that was reviewed; section 3 presents the methodology followed; section 4 reveals the results and includes a discussion; and finally, section 5 summarises and concludes the study.

\section{LITERATURE REVIEW}

The structure and efficiency of a financial system in undertaking the intermediation role, have been debated on their contribution towards stimulating economic growth. As such, any modern economy that wants to function properly needs the financial systems as its cornerstone (Adesina, 2013). A financial system can be either dominated by the banking sector or by the financial markets. The domination of either the financial markets or banking system creates a difference in roles of financial markets in different countries. Therefore, classifications of countries based on financial sectors can either be a bank-based system when banks dominate or a market-based system when financial markets dominate in the financial system. This classification is not a clear dissection as some countries can have a domination of both systems or the existence of one does not imply non-existence of the other (Mathenge \& Nikolaidou, 2018). The roles of the two financial systems differ with the economy that is dominated by banks (bank based) offering risk transformation through intertemporal risk sharing, with the financial markets sector dominated economy offering cross-sectional risk sharing (Boot \& Thakor 1997).

Although the development of the financial sector is good for growth, a number of studies (for exampleLevine \& Renelt, 1992, 2001, 2005; King \& Levine, 1993; Beck, 2008; Demirgüç-Kunt et al., 2011; Demetrious \& Hussein, 1996) have confirmed that it is imperative to note that different measures have been used and each has its own strengths and weaknesses. Financial development is an unobservable variable and proxies are usually used, with numerous studies that have made use of financial deepening measures such as the ratio of M3/GDP, domestic credit to private sector, private credit as a percentage of gross domestic product (GDP) and market capitalisation as a percentage of GDP. Literature confirms that all these measures lack balance in terms of usage, relevance and affordability of the financial services and that there is no development if the financial system cannot serve the needs of the intended users. In addition, the use of a single variable proxy of deepening of the financial sector is not sufficient and as such wrong inferences may be drawn. With this backdrop, financial deepening has been suggested to be an all-inclusive measure, with the ability to be dissected even into bank-based measure and market-based measure (Sayah et al., 2016). In that regard, financial deepening can be considered more critical for economic growth. This is because financial deepening takes into account the relevance of the product that is being provided by the financial system and as such better access of financial service for all.

Amongst many of the authors that analysed the link between financial sector depth and economic growth, Boamah, Adongo, Essieku and Lewis (2018), Osisanwo (2017), and Bist (2018) found a positive significant relationship between financial deepening and the growth of the economy, whilst using panel data. Contrary to these findings; Naceur, Blotevogel, Fisher and Shi (2017) and Demetriades and Rousseau (2016) established that financial development and financial sector depth do not always lead to growth in the economy. Panizza (2018) reviewed a spectrum of literature on empirical analysis of the finance and growth nexus. In particular, Panizza (2018) focused on literature that noted the marginal contribution of the financial sector depth towards the growth of the economy and identified that the contribution is negative in countries with larger financial sectors, such as South Africa.

The financial system positively influences economic growth, as argued by the researchers above, but it can also be the barrier to growth. Prochniak and Wasiak (2017) postulated that high levels of technological advancements and depth of the financial sector can lead to effective and efficient functioning of the sector; however, these developments can also lead to a risk which emanates from this effective functioning. The level of susceptibility of a financial system to a large scale financial crisis is also exacerbated by financial development. These authors demonstrated that the $U$ (inverted) shaped correlation exists between financial sector development and economic growth and this argument posits that the correlation is not linear.

The researchers identified the importance of the size and development of the financial sector. These authors argued that in economies with a large financial 
sector, there is not a strong link found between financial sector and economic growth. Moreover, the correlation is, to some extent, positive in economies which have a small to medium-sized financial sector. There are two key consequences of far too much global finance; first, it leads to economic booms and busting, which exacerbate countries and decrease actual GDP growth. Second, this trend of excessive finance contributes to the diverting of resources and human capital from manufacturing industries into the financial sectors. Some economists note that very large financial sectors can result in resource misallocation in relation to the size of the financial sector due to lease extraction from other business sectors.

Karimo and Ogbonna (2017) further examined an empirical analysis of the causality between deepening of the financial sector and the growth of the economy in the case of Nigeria, using Toda-Yamamot's Granger causality test as an estimation technique. The study covered the period 1970-2013. The results showed that in Nigeria's case, financial deepening follows supplyside assumptions. This means that economic growth is a product of financial deepening, while economic growth does not lead to financial deepening. The study suggests that policy needs to concentrate on removing barriers to credit growth in the private sector and should restore investor confidence in trading. More so, Osisanwo (2017) did a time series analysis, covering the period 1980-2014, and showed that in Nigeria, with the exception of the private sector credit ratio, all financial development indicators positively impact the growth of Nigeria's economy. These findings show that a combined banking sector and financial markets contribute much to sectorial output growth. Furthermore, the study identified that in the case of Nigeria, large banks need to guarantee credit facilities at a low cost of borrowing to industrial investors in order to enhance economic growth that is derived from financial sector development.

In the same context, Naceu, Blotevogel, Fischer and Shi (2017), using a sample of 145 countries between 1960-2011 for the CCA and MENA region, went beyond financial depth to capture the access of financial services in the process of financial development. Naceu, et al. (2017) further looked at other facets of development in their definition of financial sector development such as efficiency of the financial sector in performing its roles (risk and maturity transformation). The study did not only look at efficiency and access, but further broadened its definition of development in the financial sector by determining the susceptibility of the financial system through looking at its stability and openness. However, even in this broad interpretation, the results show that it does not seem to be a panacea for growth of the economy. Another study that deviated from using financial depth as a measure of development in the financial sector is one by Faisal, Türsoy and Berk (2018). In their study in northern Cyprus for the period 1978 to 2015, the authors measured financial sector development using total deposit of the banking sector, when analysing its relationship with the growth of the economy; and they used the autoregressive distributed lag (ARDL) model and combined the cointegration estimation technique to evaluate and validate this relationship. The results showed that these two cointegration methods provides strong evidence that cointegration exists between the development in the financial sector and growth. Faisal, Türsoy and Berk (2018) also further identified that when looking at the coefficients of the ARDL results, depth impacts growth positively - therefore affirming the strength of financial growth.

Bist (2018) used panel data analysis and the grouproot cointegration technique to analyse the relationship between financial sector development and economic growth for the period 1995-2014. The author established that there is a strong cointegration between the variables and also that there is cross-sectional dependency as supported by Pedmi's analysis. The findings of a long-term cointegration relationship between these two variables were coupled with coefficients indicating that economic growth in most countries in the sample of countries was positively affected by development. Similarly, private sector credit flows were found to be very low in this part of the world.

On the other hand, recent literature seems to challenge the general belief of the nexus between finance and growth, and suggests that successive increase in development would lead to the nexus either weakening when it is at best whilst the worst case would be negative at certain levels of development in the financial sector (Fink, Haiss \& Mantler, 2005).

Boamah, Adongo, Essieku and Lewis (2018) conducted an analysis of 18 Asian countries for the period 1990 to 2017, using panel data on the nexus between total fixed capital formation, financial depth and economic growth. The results of the analysis by Boamah et al. (2018) showed that total fixed capital formation and financial depth significantly impacted on growth. The study stated that a positive significant 
impact of these two variables can hinder growth. Similarly, Demetriades and Rousseau (2016) did a panel analysis of 91 countries on the relationship between development of the financial sector and growth and derived that depth of the financial sector has shifted from being a determinant of long-term growth in the economy. Demetriades and Rousseau, (2016) stated that bank regulation and supervision are the main catalysts of the finance-growth nexus. Demetriades and Rousseau (2016) also argued that the finance-growth nexus is a holistic analysis that does not only focus on the comparison of which system is better, but looks at the integration of the financial system and the structure of the economy.

Given that most of the literature suggests that financial deepening promotes growth, the authors of this paper were therefore interested in assessing the effects of bank competition on economic development. They wanted to find out whether countries with welldeveloped financial systems grow faster with more competition in their banking sector. Theory suggests that with more competition, financial systems provide a wide-range of better quality financial services at fair pricing which thus improves economic growth (Claessen \& Laeven, 2005). However, in most economies the structure of the financial sector tends to be highly concentrated, and in some cases more concentration means lower competition. Therefore, the financial deepening-growth nexus can be hampered by the nature of competition within the financial sector.

Financial sector rivalry matters for a number of reasons, among others, fair pricing, efficiency, innovation, economic growth and financial inclusion (Bikker \& Haff, 2002; Claessen \& Lauven, 2005; Ngonyama \& Simatele, 2017). On the other hand, competition is a double edged sword as too much competition can be detrimental to financial stability (Mishi, \& Khumalo, 2019). As such, it is argued that the global financial crisis aroused the interest of policy makers and academics in understanding the importance of bank competitions and the role of government in competition policies. It is therefore the belief of many that the intensification of competition and financial innovation in markets contributed to the financial turmoil. The banking sector is very delicate as it is susceptible to bank runs (Mirkin, Kuznetsova \& Kuznetsov, 2013). In measuring competition, authorities of most economies have resorted to the use of concentration indicators, where higher concentration means low competition. However, it is imperative to understand that measures of concentration are generally not good predictors of competition. There are various factors to be taken into account, which when considered more often, the use of concentration indicators as proxy for competition is refuted. A good example would be the consideration for entry and exit restrictions - most economies' banking sectors are liberalised by reforms, making entry and exit very easy. In that regard, banks are pressured to behave competitively in such reformed economies despite the levels of concentration, as there is an impending threat of entry for new players or exit of underperforming ones.

The direct measures of competition from the pricing behaviour and or market power have been suggested and are becoming very popular across literature. Examples of such measures include the "PanzarRosse $\mathrm{H}$-statistic, the Lerner index, and the Boone indicator" (Beck, 2008; Boone, 2001; Panzar, \& Rosse, 1987; Leon, 2014 p.7). The newly added Boone metric, on the other hand, tests the effect of productivity on performance as regards to profit. Through calculation, it is the elasticity of profit to marginal costs, with elasticity measured as the log of a profit measure (for example, return on assets) regressed against a marginal cost log measure (Boone, 2001). From the indicator's point of view, and through its conceptualisation, higher profits are realised by the banks performing most.

\subsection{Conceptualising Financial Deepening}

Literature has provided mainly four indicators for financial deepening in the financial institutions as a percentage of GDP. These are "private sector credit, pension fund assets, mutual fund assets, and premiumlife and non-life insurance premiums" (Martynova, $2015: 13)$. On the other hand, a number of indicators are measures for financial deepening in financial markets. The metrics include the stock traded to GDP (market liquidity), stock market capitalisation to GDP etc. In addition, the other metrics are (as a percentage of GDP): international debt securities of government, total non-financial corporate debt securities, and total financial corporate debt securities (Nyantakyi \& Sy, 2015).

Several indicators, including domestic credit as percentage of GDP to the private sector, are employed for measurement of financial growth. This indicator is the most popular in the literature and covers claims of the private sector by receiving deposits in relation to economic activity from financial institutions. The measure thus describes the role played by financial 
Table 1: Financial Deepening Component Indicators

\begin{tabular}{|c|c|}
\hline "Financial institutions & Financial markets \\
\hline \hline 1. Private-sector credit (\% of GDP) & 1. Stock market capitalisation to GDP \\
2. Pension fund assets (\% of GDP) & 2. Stocks traded to GDP \\
3. Mutual fund assets (\% of GDP) & 3. International debt securities government (\% of GDP) \\
4. Insurance premiums, life and non-life (\% of GDP) & 4. Total debt securities of nonfinancial corporations (\% of GDP)" \\
\hline
\end{tabular}

Source: Authors computation based on literature (Nyantakyi \& Sy, 2015; King \& Levine, 1993).

intermediaries in channelling private sector investors' savings. Higher value, more depth, implies the provision of financial services enhancing productivity, and is good for the economy (King \& Levine, 1993).

Table 1 above summarises the financial deepening component indicators.

The most popular indicator, according to the literature, is private sector claims in respect of economic activity by receiving deposits from financial institutions. The measure shows the role of financial intermediaries in the channelling of private sector investment savings. Higher value and more depth mean that financial services are productive and economically beneficial (King \& Levine, 1993). The principal component analysis (PCA) was used to compute a composite indicator and this approach is explained below.

\subsection{Principal Component Analysis Application}

Principal component analysis (PCA) is a mathematical and statistical transformation method to turn an observation set of possibly associated variables into linearly unrelated values known as principal components by using an orthogonal transformation (Lenka, 2015). The principal components should be less than or equal to one, according to the statistical procedure. There are fewer or similar numbers of major components than the initial element. When the dataset is commonly distributed, the principal components are considered to be distinct. This study built a financial deepening index to follow up the evolution of the financial sector as a whole because there is no single aggregate index. The study used the principal method of combining the eight selected financial deepening measures with one index. The jth factor $\mathrm{Fj}$ factor can be expressed as: According to this procedure:

$F j=W_{j 1} X_{1}+W_{j 2} X_{2}+W_{j 3} X_{3}+\cdots_{. .}+W_{j p} X_{p}$

Where: $\mathrm{Fj}=$ estimate of $\mathrm{jth}$ factor $\mathrm{Wj}=$ weight on factor score coefficient $P=$ number of variables
In this study, financial deepening indices were constructed using PCA, namely:

- Financial institutions deepening (factor extracted)

- $\quad$ Stock markets deepening (factor extracted)

- Overall financial system deepening (hybrid factor extracted, combing the above two).

\section{METHODOLOGY AND EMPIRICAL RESULTS}

\subsection{Data Sources and Frequency}

The study employed yearly panel data for the period 1999-2014 for 64 developing countries with an unbalanced panel. The data was obtained from World Bank's Global Financial Development Database. The data was pooled into a panel data set and estimated by means of panel data regression analysis. The panel data estimation system allows control of unobserved and omitted variables. More so, the estimation technique controls for heterogeneity bias within the regression model as well as within the selected individual sectors.

The study model was based on Gambacorta, Yang and Tsatsaronis (2014). The modified form $i$ set as follows:

$E D_{i t}=\alpha+\beta_{1} C_{i t}+\beta_{2} D T_{i t}+\beta_{3} Z_{i t}+\varepsilon_{i t}$

Where:

$E D=$ Economic growth and GDP per capita

$\mathrm{C}=$ Vector of competition measures (concentration measures; boon indicator; Lerner index)

DT = Vector of financial depth measures (banking sector depth; capital market depth; overall financial system depth (used interchangeably with the first two separate indicators).

$Z$ = Vector of control variables 


\subsubsection{Definition of Variables}

As indicated in the foregoing sections, the variables to explain financial depth, competition and economic performance are properly defined here for clarity and description of empirical usage to determine suitability.

\subsubsection{Economic Growth and GDP Per Capita}

In the work of Birdsall and Hamoudi, (2002), and Sarkar, (2006), the World Bank defined economic growth as an increase in a intertemporal capacity of a country to achieve productivity and it is usually measured by the GDP. However, due to variability of exchange rate and population across countries being reviewed in this study, a population adjusted GDP presented in USD, that is GDP per capita, was used to account for the disparities in these indices.

\subsubsection{Financial Depth Measures}

Financial depth, according to the World Bank, is referred to as the volume of a country's financial apparatus, like the banks and non-bank financial institutions and its financial markets, taken in comparison with an index of economic output (World Bank, 2012). Private credit percentage of GDP has particularly gained popularity in much empirical literature as a proxy for financial depth. Other popular measures of financial depth are stock market capitalisation to GDP and private debt securities to GDP (World Bank, 2016). A combination of both captures the total sum of the depth of financial structures or system of a country, hence the adoption as proxy for financial depth in the countries within the panel (World Bank, 2016)

\subsubsection{Financial Competition Measures}

Financial competition is described as the interplay of transactional activities ethically aimed at outscoring or outperforming competitors for the share of the market within the financial system (Coccorese, 2017; Gaffeo \& Mazzocchi, 2014; Ngonyama \& Simatele, 2017). According to Ngonyama and Simatele (2017), there are two broad measures of capturing competition, namely the Traditional Measures and the New Empirical Industrial Organization (NEIO). While the Traditional Measures capture competition from indirect proxies, indicators such as the bank assets of the three largest banks (bank concentration) and HerfindahlHirschman index, are often used, among others. This study adopted the traditional approach creating a vector of competition measures to be bank asset concentration and bank concentration. To capture market power we employ two measures, namely Boone indicator and Lerner index. A vector of the control variables captured with measures such as inflation (macroeconomic uncertainty), remittance flows (proxy for brain drain), ATMs proxy for financial inclusion as well as bank-specific factors such as banks' return on assets (ROA), banks' return on equity (ROE) to address disparity as may be observable across the cross sections in the panel.

\section{ESTIMATION PROCEDURES AND RESULTS}

This part of the paper provides an overall framework for the study with the main focus directed towards the panel estimation techniques employed which include fixed effects (FE) and pooled ordinary least squares (POLS) (Baltagi, 2005) as well as several diagnostic checks. Each country is assumed to have individual characteristics that can affect the predictor variables and to have a unique and uncorrelated error term and constant compared to the other countries (Brooks, 2014). A fixed-effect model was chosen accordingly. The Hausman's test hypothesis of random adequately modelling the individual effects was resoundingly rejected.

The Hausman test was done to make sure that a random and fixed model was best assumed, since the model of fixed effects also clearly estimates whether the data production process has a fixed effect or random effect, with random effects being more efficient. The random effects model provides accurate estimates only if the method of generating data is random (i.e., all the calculated properties for a specific cross-section are time-different). The findings of the study are presented in Table 2 and Table 3 below. The first two columns present results of overall financial system deepening, while the last two take into account financial institutions' deepening separately from stock market deepening.

Table 2 (below) and Table 3 (below) show a positive and significant impact on economic growth and per capita GDP, including financial integration, bank concentration, inflation, and the financial system depth. ROE of banks only has a positive effect on GDP. The results also show that GDP movements are only positively linked to changes in GDP in central bank assets. Although the competition from the Learner index in banks has a significant and positive impact on GDP per capita, the effect on economic growth is not the same as the impact on economic growth of both competitive behaviours (the Learner index and the Boone indicator).

The positive relationship between economic growth and financial depth and GDP per capita is consistent 
Table 2: Effect of Financial Deepening and Competition on Economic Growth

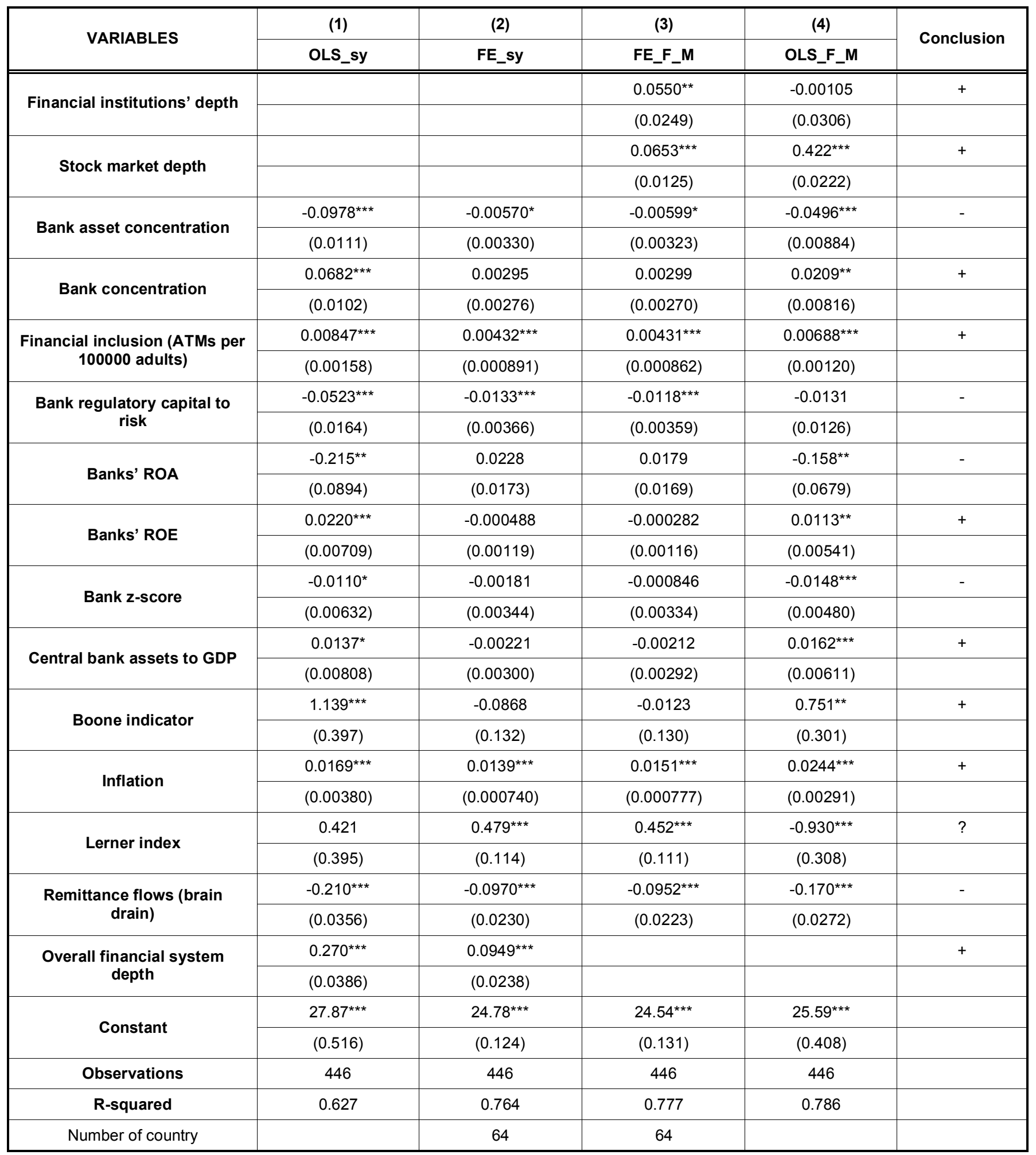

Standard errors in parentheses.

${ }^{* * *} p<0.01,{ }^{* *} p<0.05,{ }^{*} p<0.1$.

with the study's predicted apriori. Table 3's empirical results indicate that at $5 \%$ significance level, a unit increase in financial institutions' depth results in a 5\% increase in GDP per capita and 17\% GDP at $10 \%$ significance level. The results were consistent with Čihák, Demirgüç-Kunt, Feyen, and Levine (2015), who indicated that financial markets and financial institutions are greatly influenced by economic stability, 
alleviation of poverty and development of the economy. Regardless of the matter, financial markets are known to destabilise the economy and restrict the growth of the economy.

Again, the stock market has a positive and significant impact on economic performance and GDP per capita as presented in Tables $\mathbf{2}$ and $\mathbf{3}$. Thus, a unit change in stock market depth increases in economic performance by $6 \%$ to $40 \%$ and $2 \%$ at $1 \%$ level respectively. The findings are in line with the apriori expectation, meaning that an increase in the stock market prompts creation of liquidity. Therefore, high liquid market investments are less risky and more attractive as they allow the savers to acquire more assets and sell fast at low prices (Levine, 1996). This increases in the allocation of capital; enhanced per capita GDP as well as GDP growth are driven by more profitable investment and liquid market growth. Beck and Levine (2004) also agreed with the empirical results, which indicate that stock markets have a positive effect on economic growth.

Additionally, the findings show that a high concentration of bank assets improved economic performance and GDP by $4 \%$ to $9 \%$ at significance levels of $1 \%$ and $5 \%$ (Table 2). Antony and Aboagye (2012) shared their opinion that a concentration of banking assets has a good relationship with the performance of both deposits and credit markets. The operating cost elasticity of deposits exceeds the elasticity of loans. Nonetheless, the concentration of bank assets decreases significantly by $4 \%$ per capita income at $1 \%$ significance level (Table 3 ). The apriori expectation of the study is not compatible. In principle, the impact of the concentration of bank assets on economic growth depends on their proximity to the global frontier with technology. In line with the theory of Diallo and Koch (2018), the negative coefficient is predicted to have a negative and significant effect on economic growth, especially in countries close to the frontier.

According to the results in Tables $\mathbf{2}$ and $\mathbf{3}$, financial inclusion (ATM per 10000) has positive coefficient and it is significant at the $1 \%$ level. This result suggests a direct relationship between financial inclusion, economic growth and output per capita. It indicates that a unit increase in financial inclusion will increase economic growth by about $4 \%$ to $8 \%$ and GDP per capita by $2 \%$. This result accords the apriori proposition of this paper. Likewise, the results are with who suggest that financial inclusion results in improvement in quantity, quality, and efficiency of financial intermediary services. The findings of the financial inclusion as well as size, price, and productivity of financial intermediate services are consistent to those of Abiola, Adegboye and Alexander, (2015). Hence, local savings increase productive investments in local businesses and economic growth. More so, findings reveal that a unit increase in banks' ROE will increase output growth by $1 \%$ to $2 \%$. This is in line with Alkhazaleh (2017) who revealed that measures of bank performance have a positive relationship with economic growth, measured by GDP, especially profitable deposits

The findings of this study show that inflation has a positive impact on economic performance. Monetary policies of the selected countries should therefore concentrate on managing demand as an incentive for growth rather than inflation targeting. These findings are consistent with the results of Pollin and Zhu (2006) who argued that inflation is positively related to GDP in low income countries.

The results also indicate that the financial system's overall complexity and economic performance are directly related. The total size of the financial system grew by approximately $20 \%$ over the period, rising GDP and GDP per capita. The overall financial system depth has a positive and significant impact on economic performance. Thus, a unit change in this variable increases economic growth by $9 \%$ to $20 \%$ at the $1 \%$ significant level. This could be attributed to an expanded financial system for mobilising savings and for the development process to be distributed. The results are consistent with the findings of Kargbo and Adamu (2010) that the positive and statistically significant impact of financial developments on economic growth is a vital pathway through which financial growth drives growth.

The empirical results also show that the bank regulatory capital to risk, bank ROA and bank remittance flows (brain drain) have a negative and significant impact on economic growth and GDP per capita. However, the bank $Z$ score has a negative effect on GDP only. Although the central bank assets to GDP positively affect economic growth, the effect is not the same on GDP per capita.

The goal of the regulation of capital is to ensure that banks maintain a capital level consistent with their risk exposures as their risk position is altered by endogenous or exogenous factors. The empirical 
Table 3: Effects of Financial Deepening and Competition on Economic Development (GDP Per Capita)

\begin{tabular}{|c|c|c|c|c|c|}
\hline \multirow{2}{*}{ VARIABLES } & (1) & (2) & (3) & (4) & \multirow{2}{*}{ Conclusion } \\
\hline & OLS_sy & FE_sy & FE_F_M & OLS_F_M & \\
\hline \multirow{2}{*}{ Financial institutions' depth } & & & 0.0121 & $0.174^{\star * *}$ & + \\
\hline & & & $(0.0104)$ & $(0.0320)$ & \\
\hline \multirow{2}{*}{ Stock market depth } & & & $0.0204^{* * *}$ & 0.0318 & + \\
\hline & & & $(0.00523)$ & $(0.0233)$ & \\
\hline \multirow{2}{*}{ Bank asset concentration } & 0.00289 & $-0.00453^{* * *}$ & $-0.00454^{* * *}$ & 0.00463 & - \\
\hline & $(0.00883)$ & $(0.00136)$ & $(0.00135)$ & $(0.00926)$ & \\
\hline \multirow{2}{*}{ Bank concentration } & 0.00379 & $0.00274^{\star *}$ & $0.00269^{* *}$ & 0.00202 & + \\
\hline & $(0.00809)$ & $(0.00114)$ & $(0.00113)$ & $(0.00854)$ & \\
\hline \multirow{2}{*}{ Fin inclusion (atms per 100000 adults) } & $0.0145^{\star \star *}$ & $0.00206^{\star \star \star}$ & $0.00207^{\star * *}$ & $0.0144^{\star \star *}$ & + \\
\hline & $(0.00125)$ & $(0.000368)$ & $(0.000361)$ & $(0.00126)$ & \\
\hline \multirow{2}{*}{ Bank regulatory capital to risk } & $-0.0444^{* * *}$ & $-0.00786^{* * *}$ & $-0.00734^{* * *}$ & $-0.0425^{* * *}$ & - \\
\hline & $(0.0130)$ & $(0.00151)$ & $(0.00150)$ & $(0.0132)$ & \\
\hline \multirow{2}{*}{ Banks ROA } & $-0.213^{* * *}$ & 0.00968 & 0.00812 & $-0.209^{* * *}$ & - \\
\hline & $(0.0710)$ & $(0.00715)$ & $(0.00708)$ & $(0.0710)$ & \\
\hline \multirow{2}{*}{ Central bank assets to GDP } & $-0.0256^{\star * *}$ & -0.000784 & -0.000761 & $-0.0251^{* * *}$ & - \\
\hline & $(0.00641)$ & $(0.00124)$ & $(0.00122)$ & $(0.00639)$ & \\
\hline \multirow{2}{*}{ Boone indicator } & $-0.811^{* *}$ & $-0.104^{*}$ & -0.0781 & $-0.815^{\star *}$ & - \\
\hline & $(0.315)$ & $(0.0545)$ & $(0.0545)$ & $(0.316)$ & \\
\hline \multirow{2}{*}{ Inflation } & -0.000738 & $0.00358^{* * *}$ & $0.00397^{* * *}$ & -0.000581 & + \\
\hline & $(0.00301)$ & $(0.000305)$ & $(0.000325)$ & $(0.00304)$ & \\
\hline \multirow{2}{*}{ Lerner index } & $1.174^{\star \star *}$ & $0.116^{* *}$ & $0.106^{\star *}$ & $1.137^{* \star *}$ & + \\
\hline & $(0.313)$ & $(0.0472)$ & $(0.0466)$ & $(0.323)$ & \\
\hline \multirow{2}{*}{ Remittance flows (brain drain) } & $-0.0702^{* *}$ & -0.0102 & -0.00988 & $-0.0654^{* *}$ & - \\
\hline & $(0.0283)$ & $(0.00949)$ & $(0.00936)$ & $(0.0284)$ & \\
\hline \multirow{2}{*}{ Overall financial system depth } & $0.193^{\star \star *}$ & $0.0280^{\star \star *}$ & & & + \\
\hline & $(0.0306)$ & $(0.00983)$ & & & \\
\hline \multirow{2}{*}{ Constant } & $8.319^{\star * *}$ & $8.730^{\star \star *}$ & $8.653^{* * *}$ & $8.169^{\star * *}$ & \\
\hline & $(0.410)$ & $(0.0514)$ & $(0.0549)$ & $(0.427)$ & \\
\hline Observations & 446 & 446 & 446 & 446 & \\
\hline R-squared & 0.663 & 0.604 & 0.615 & 0.664 & \\
\hline Number of country & & 64 & 64 & & \\
\hline
\end{tabular}

Standard errors in parentheses

${ }^{* * *} p<0.01,{ }^{* *} p<0.05,{ }^{*} p<0.1$.

results show that the bank regulatory capital risk has a negative relationship with GDP, meaning that high bank regulatory risk hinders economic performance by $1 \%$ to $7 \%$. The fact that credit supply and credit demand can be cut through rising loan rates, which may slow economic growth in view of higher capital requirements, was confirmed by Martynova (2015). Increased capitalisation of banks increases financial stability; however, this is by decreasing bank risk-taking opportunities and increasing bank reserves against losses.

Regarding the bank ROA, when the bank ROA is high it leads to about $15 \%$ to $21 \%$ decline in economic performance at $10 \%$ significant level. The negative relationship is not in accordance with the apriori suggestion. The negative coefficient could probably be because of ineffective management and inefficient 
competitive strategies in using assets to generate earning, leading to a drop in economic growth.

More so, a unit increase in the bank $Z$ score decreases economic performance by $1 \%$. This variable is not consistent with the study's apriori proposition. Soedarmono, Machrouh and Tarazi (2011) consistently indicated that their default risks remained higher, although they had been better capitalised in a less competitive market. However, a more in-depth study showed that such behaviour is economically dependent. Higher economic growth leads to the neutralisation, in less competitive markets, of increased risk-taking and stability.

The results in Table 2 show that the central bank assets to GDP have a positive and significant relationship with economic performance, and thus a unit increase in the variable increases economic performance by $10 \%$ at the $5 \%$ level. However, the effect is not the same for GDP per capita as presented in Table 3. The negative relationship implies that growth enhancing does not necessarily/directly translate to development (growth inclusivity/ equity). In line with King and Levine (1993), the central bank assets ratio decreases with income growth.

More so, the remittance flow (brain drain) has a negative and significant impact on economic performance, meaning that a unit change in remittance flow will reduce economic performance by $1 \%$ to $20 \%$ and GDP per capita by $6 \%$ to $7 \%$ at the 1 to $5 \%$ significance level respectively. A negative coefficient of remittances' flow indicates that remittances in receiving economies have the potential to appreciate the real exchange rate, thereby hurting the prospects of competitiveness of the export sector (AmuedoDorantes \& Pozo, 2004). Moreover, remittances can actually harm the competitiveness of the export sector in the receiving countries. This finding is similar to the effects of Dutch Disease in economies with large flow of foreign exchange (Termos et al., 2013).

The results of the study indicate that the bank competition, as measured by the Learner index and Boone indicator, positively and negatively affects the output per capita respectively. However, both measures have an insignificant effect on economic growth. Table 3 indicates that the Lerner index has a positive sign and it is significant at the $5 \%$ level. This suggests a direct relationship between the Lerner index and GDP per capita. This implies that an increase in bank competition boosts GDP per capita by $10 \%$ to
$11 \%$. The positive coefficient could be a result of low interest rates due to a competitive environment, interest rates on loans are low, and hence there will be more access to credit by firms, thereby increasing income per capita. This confirms Masahito's (2013) work that suggested that a positive effect of competition as measured by the Lerner index on the output growth rate is clearly observable in the Japanese manufacturing industries.

Also, the results are in line with Gaffeo and Mazzocchi (2014) who recommended a strong bidirectional causality running from GDP to the banking competitiveness in OECD countries. In contrast, an increase in the Boone indicator drops per capita income by $10 \%$ at the $10 \%$ level. This could result from insufficient market power for banks, which means that they lack sufficient information on borrower companies and hence they will be hesitant to lend to their customers. In addition, this will have a negative impact on their financial practices and, in general, on their economic performance. The results are consistent with Coccorese (2017) who posited that too much competition among banks is not profitable for the economy.

\section{CONCLUSION AND POLICY IMPLICATIONS}

The aim of the study was to investigate the effect of financial deepening and competition on economic performance. The study found that financial depth is growth and development enhancing and that financial institutions' depth has greater effect on GDP per capita than markets' depth. The results also revealed that stock markets' development is growth enhancing but may not translate to economic development, as access to stock markets may be limited to few players in the economy. This implies that stock markets' development may not aid in addressing inequality, instead it has the potential to perpetuate it. This is mainly because financial markets are accessible to few with resources that allow entry and continued participation. In the case of South Africa, there has been criticism in terms of demographics of participants on the Johannesburg Stock Exchange (JSE), which is argued to be dominated by a minority population group and this is true for many developing countries.

Central banks should facilitate effective methods of refinancing credit channels and liquidity for private companies and follow an aggressive policy to resolve any barriers to the growth of both the private and public sectors in the financial deepening phase. Thus, 
financial deepening policies and the competition between banking institutions should be improved so that money deposit banks are free from high incidences of poor performing loans, and thus their capacities to extend credit to the economy should be enhanced. In order to encourage potential investors to increase investment and increase the economy's growth, the government ought to embolden monetary authorities such as central banks to create a favourable and affordable environment for friendly interest rates. This can be achieved by requiring low reserves and by providing adequate financial and physical infrastructure to eliminate economic barriers. Investment decisions and economic savings are stimulated by the interest rate.

The capital market remains shallow and bottlenecks are preventing ease of doing business, with political efforts aimed at refurbishing investor confidence by strengthening the regulatory structures and legal frameworks for stocks and fostering stability and the efficiency of stock markets. This also ensures that stock prices represent the true values or future profitability of companies. Further studies can also proceed by investigating the interaction of depth and competition-need and testing the intermediated relationship.

\section{REFERENCES}

Abiola, B. A, Adegboye, F. B., and Alexander, O. (2015). Financial Inclusion and Economic Growth in Nigeria. International Journal of Economics and Financial Issues, 5(3), pp. 31373156.

Adesina, K.S., (2013). Modelling stock market return volatility: GARCH evidence from Nigerian Stock Exchange. International journal of financial management, 3(3), p.37.

Adu, G, Marbuah, G., \& Tei, J. (2014). Financial development and economic growth in Ghana: Does the measure of financial development matter? Journal of Advanced Research, (July 2013). https://doi.org/10.1016/j.rdf.2013.11.001

Adu, G., Marbuah, G., and Mensah, J. T. (2013). Financial development and economic growth in Ghana: Does the measure of financial development matter? Review of Development finance, 3(4), pp. 192-203. https://doi.org/10.1016/j.rdf.2013.11.001

Akinlo, A. E., \& Akinlo, O. O. (2009). Stock market development and economic growth: Evidence from seven sub-Sahara African countries. Journal of Economics and Business, Elsevier, 61(2), 162-171. https://doi.org/10.1016/j.jeconbus.2008.05.001

Alkhazaleh, A.M.K. (2017). Does banking sector performance promote economic growth? case study of Jordanian commercial banks. Problems and Perspectives in Management, 15(2), pp. 55-64. https://doi.org/10.21511/ppm.15(2)

Amuedo-Dorantes, C. and Pozo, S. (2004). Workers' remittances and the real exchange rate: a paradox of gifts. World development, 32(8), pp.1407-1417. https://doi.org/10.1016/j.worlddev.2004.02.004
Andersen, T. B. and Tarp, F. (2003). Financial liberalization, financial development and economic growth in LDCs. Journal of International Development: The Journal of the Development Studies Association, 15(2), pp. 189-209. https://doi.org/10.1002/jid.971

Antony, Q. and Aboagye, Q. (2012). Bank Concentration And Economic Costs Of Deposit Mobilization And Credit Extension In Ghana. Journal of Developing Areas, 46(2), pp. 351-370.

https://doi.org/10.1353/jda.2012.0023

Baltagi, B. H. (2005). Econometric Analysis of Panel Data, John Wiley\&Sons Ltd. West Sussex, England.

Beck, T. (2008). Bank competition and financial stability: friends or foes? The World Bank. https://doi.org/10.1596/1813-9450-4656

Beck, T. and Levine, R. (2004). Stock markets, banks, and growth: Panel evidence. Journal of Banking and Finance, 28(3), pp. 423-442. https://doi.org/10.1016/S0378-4266(02)00408-9

Bernard, A. U., and Austin, A. (2011). The role of stock market development on economic growth in Nigeria: A time-series analysis. African Research Review, 5(6), pp. 213-230. https://doi.org/10.4314/afrrev.v5i6.18

Bikker, J. A., and Haaf, K. (2002). Competition, concentration and their relationship: An empirical analysis of the banking industry. Journal of banking \& finance, 26(11), pp. 21912214. https://doi.org/10.1016/S0378-4266(02)00205-4

Birdsall, N. and Hamoudi, A., (2002). Commodity dependence, trade, and growth: when'openness' is not enough. Center for Global Development Working Paper, (7). https://doi.org/10.2139/ssrn.999988

Bist, J. P. (2018). Financial development and economic growth: Evidence from a panel of 16 African and non-African lowincome countries. Cogent Economics \& Finance, 6(1), Article Number 1449780. https://doi.org/10.1080/23322039.2018.1449780

Boamah, J., Adongo, F. A., Essieku, R., and Lewis Jr, J. A. (2018). Financial Depth, Gross Fixed Capital Formation and Economic Growth: Empirical Analysis of 18 Asian Economies. International Journal of Scientific and Education Research, 2(04). https://doi.org/10.2139/ssrn.3424688

Boone, A.L. and Mulherin, J.H., 2011. Do private equity consortiums facilitate collusion in takeover bidding?. Journal of Corporate Finance, 17(5), pp.1475-1495. https://doi.org/10.1016/j.jcorpfin.2011.08.007

Boone, J. (2001). Intensity of competition and the incentive to innovate. International Journal of Industrial Organization, 19(5), 705-726.

Boot, A. W., and Thakor, A. V. (1997). Financial system architecture. The Review of Financial Studies, 10(3), pp. 693-733. https://doi.org/10.1093/rfs/10.3.693

Boyd, J. H., Levine, R., and Smith, B. D. (2001). The impact of inflation on financial sector performance. Journal of monetary Economics, 47(2), pp. 221-248. https://doi.org/10.1016/S0304-3932(01)00049-6

Brooks, C., 2014. Introductory Econometrics For Finance (3rd Edition). Camebridge. https://doi.org/10.1017/CBO9781139540872

Buffie, E. (1984). Financial repression, the new structuralists, and stabilization policy in semi-industrialized economies. Journal of Development Economics, 14(3), 305-322. https://doi.org/10.1016/0304-3878(84)90061-0

Čihák, M., Demirgüç-Kunt, A., Feyen, E., \& Levine, R. (2015). Financial Perspectives. The Corporate L.I.F.E Centre International Inc., 1(3), 1-6. Retrieved from http://www.theclci.com/products_pmms-bsc01.htm 
Claessens, S. and Laeven, L. (2005). Financial dependence, banking sector competition, and economic growth. Journal of the European Economic Association, 3(1), pp. 179-207. https://doi.org/10.1162/1542476053295322

Coccorese, P. (2017). Banking Competition and Economic Growth. Chapter in: Handbook of Competition in Banking and Finance, Chapter 12, pp.230-263, Edward Elgar Publishing. https://doi.org/10.4337/9781785363306.00020

Demetriades, P. O. and Hussein, K. A. (1996). Does financial development cause economic growth? Time-series evidence from 16 countries. Journal of development Economics, 51(2), 387-411. https://doi.org/10.1016/S0304-3878(96)00421-X

Demetriades, P. O. and Rousseau, P. L. (2016). The changing face of financial development. Economics Letters, 141, pp. 87-90. https://doi.org/10.1016/j.econlet.2016.02.009

Demirgüç-Kunt, A., Córdova, E. L., Pería, M. S. M. and Woodruff, C. (2011). Remittances and banking sector breadth and depth: Evidence from Mexico. Journal of Development Economics, 95(2), pp. 229-241.

https://doi.org/10.1016/j.jdeveco.2010.04.002

Diallo, B. and Koch, W. (2018). Bank Concentration and Schumpeterian Growth: Theory and International Evidence, The Review of Economics and Statistics, MIT Press, Vol. 100(3), pp 489-501. https://doi.org/10.1162/rest a 00679

Ductor, L. and Grechyna, D. (2015). Financial Development, real sector, and economic growth. International Review of Economics and Finance, 37, pp. 393-405. https://doi.org/10.1016/j.iref.2015.01.001

Durusu-Ciftci, D., Ispir, M.S., and Yetkiner, H. (2017). Financial development and economic growth: Some theory and more evidence. Journal of Policy Modelling, 39(2), pp.290-306. https://doi.org/10.1016/j.jpolmod.2016.08.001

Faisal, F., Tursoy, T. and Berk, N. (2018). Linear and non-linear impact of Internet usage and financial deepening on electricity consumption for Turkey: empirical evidence from asymmetric causality. Environmental Science and Pollution Research, 25(12), pp. 11536-11555.

https://doi.org/10.1007/s11356-018-1341-7

Faisal, F., Tursoy, T. and Berk, N., 2018. Linear and non-linear impact of Internet usage and financial deepening on electricity consumption for Turkey: empirical evidence from asymmetric causality. Environmental Science and Pollution Research, 25(12), pp.11536-11555. https://doi.org/10.1007/s11356-018-1341-7

Fernández de Guevara, J., \& Maudos, J. (2011). Banking competition and economic growth: cross-country evidence. The European Journal of Financ, 17(8), 739-764. https://doi.org/10.1080/1351847X.2011.554300

Fink, G., Haiss, P.R. and Mantler, H.C., 2005. The Finance-Growth Nexus: Market Economies vs. Transition Countries. Transition Countries (February 2005). https://doi.org/10.2139/ssrn.863424

Gaffeo, E. and Mazzocchi, R. (2014). Competition in the banking sector and economic growth: Panel-based international evidence. Unpublished Manuscript. https://doi.org/10.2139/ssrn.2416379

Gambacorta, L., Yang, J., and Tsatsaronis, K. (2014). Financial structure and growth. BIS Quarterly Review, March.

Goldsmith, R. . (1969). Financial Structure and Development,. Yale University Press.

Görg, H, Krieger-Boden, C,. Moran, T, and Seric, A,. (2017). "How to attract Quality FDI?." G20 Insights: G20 Germany.

Hong Vo, D., Van Huynh, S., The Vo A. and Thi-Thieu Ha, D. (2019). The Importance of the Financial Derivatives Markets to Economic Development in the World's Four Major Economies, Journal of Risk and Financial Management, MDPI, Vol. 12 (35), pp.1-18. https://doi.org/10.3390/irfm12010035
Kargbo, S. M., and Adamu, P. A. (2010). Financial Development and Economic Growth in Sierra Leone. Journal of Monetary and Economic Integration, 9(2), pp.1-32.

Karimo, T. and Ogbonna, O. (2017). Financial deepening and economic growth nexus in Nigeria: Supply-leading or demand-following? Economies, MDPI, Open Access Journal. Vol. 5(1), pp. 1-18. https://doi.org/10.3390/economies5010004

King, R. G. and Levine, R. (1993). Finance, entrepreneurship and growth. Journal of Monetary economics, 32(3), pp. 513-542. https://doi.org/10.1016/0304-3932(93)90028-E

Lenka, S.K., (2015). Measuring financial development in India: A PCA approach. Theoretical \& Applied Economics, 22(1).

Leon, F. (2015). Measuring competition in banking: A critical review of methods. Available at: https://halshs.archivesouvertes.fr/halshs-01164864/file/2015.16.pdf

Levine, R. (2002). Bank-based or market-based financial systems: which is better? Journal of Financial Intermediation, 11(4), pp. 398-428. https://doi.org/10.1006/jifin.2002.0341

Levine, R. (2005). Finance and growth: theory and evidence. Handbook of economic growth, 1, pp. 865-934. https://doi.org/10.1016/S1574-0684(05)01012-9

Levine, R. and Renelt, D., (1992). A sensitivity analysis of crosscountry growth regressions. The American economic review, pp.942-963.

Levine, R. and Zervos, S. (1998). Stock markets, banks, and economic growth. The American Economic Review, pp. 537558. https://doi.org/10.1596/1813-9450-1690

Levine, Rose. (1996). Stock markets: A spur to Economic Growth. Finance and Development. Sierra Leone. Journal of Monetary and Economic Integration, 9(2), 1-32.

Loayza, N., and Ranciere, R. (2004). Financial development, financial fragility, and growth (No. 5-170). International Monetary Fund. https://doi.org/10.1596/1813-9450-3431

Mahonye, N. and Ojah, K., 2014. Financial structure and economic development in Africa. Economic Research Southern Africa, 482.

Martynova, N. (2015). Effect of bank capital requirements on economic growth: a survey. De Nederlandsche Bank Working Paper, (467), pp. 1-25. https://doi.org/10.2139/ssrn.2577701

Masahito, A. (2013). Does Competition Improve Industrial Productivity ?: An analysis of Japanese industries on the basis of the industry-level panel data. Discussion Papers 13098, Research Institute of Economic, Trade and Industry (RIETI)

Mathenge, N. and Nikolaidou, E. (2018). Financial structure and economic growth: Evidence from Sub-Saharan Africa. Economic Research Southern Africa working paper, 732.

Mirkin, Y., Kuznetsova, O. and Kuznetsov, A. (2013). The financial depth of emerging markets: The case of Russia. Competition \& Change, 17(2), pp. 156-175. https://doi.org/10.1179/1024529413Z.00000000031

Mishi, S. and Khumalo, S.A., 2019. Bank stability in South Africa: what matters?. Banks \& bank systems, (14, Iss. 1), pp.122136. https://doi.org/10.21511/bbs.14(1).2019.11

Mitchener, K. J., \& Wheelock, D. C. (2013). Does the structure of banking markets affect economic growth? Evidence from U.S. state banking markets. Explorations in Economic History, 50(2), 161-178. https://doi.org/10.1016/j.eeh.2012.09.004

Naceur, M. S. B., Blotevogel, M. R., Fischer, M. M., \& Shi, H. (2017). Financial development and source of growth: New evidence. International Monetary Fund. 
Ngonyama N. and Simatele, M.C. (2017). Literature review Banking Competition and Access to financial Services. Economic Society of South Africa, Bi-annual Conference, 2017, Rhodes University, South Africa

Nyantakyi, E.B and Sy, M. (2015). The banking system in Africa: Main facts and challenges. Africa Economic Brief, 6(5), PP. 1-16.

Odedokun, M. O. (1996). Alternative econometric approaches for analysing the role of the financial sector in economic growth: Time-series evidence from LDCs. Journal of Development Economics, 50(1), pp. 119-146. https://doi.org/10.1016/0304-3878(96)00006-5

Osisanwo, B.G., 2017. Financial Development and Economic Growth Nexus in Nigeria: Further Evidence from Long-run Estimates. Acta Universitatis Danubius. Economica, 13(3).

Panizza, U. (2018). Nonlinearities in the relationship between finance and growth. Comparative Economic Studies, 60(1), pp. 4453. https://doi.org/10.1057/s41294-017-0043-3

Panzar, J.C. and Rosse, J.N. (1987). Testing for 'Monopoly' Equilibrium. Journal of Industrial Economics, Vol. 35, pp. 443-456. https://doi.org/10.2307/2098582

Pollin, R. and Zhu, A. (2006). Inflation and economic growth: a crosscountry nonlinear analysis. Journal of Post Keynesian Economics, 28(4), pp. 593-614. https://doi.org/10.2753/PKE0160-3477280404

Prochniak, M. and Wasiak, K. (2017). The impact of the financial system on economic growth in the context of the global crisis: Empirical evidence for the EU and OECD countries. Empirica, 44(2), pp. 295-337.

https://doi.org/10.1007/s10663-016-9323-9

Sarkar, P. (2006). Trade Openness and Growth: Is There Any Link? SSRN, 3624(2008). https://doi.org/10.2139/ssrn.952151

Sayah, M., 2016. Analyzing and Comparing Basel's III Sensitivity Based Approach for the interest rate risk in the trading book. https://doi.org/10.11114/afa.v2i1.1300

Schumpeter, J. A. (1982). The theory of economic development: An inquiry into profits, capital, credit, interest, and the business cycle (1912/1934). Transaction Publishers.-1982.-January, $1,244$.

Soedarmono, W., Machrouh, F. and Tarazi, A. (2011). Bank market power, economic growth and financial stability: Evidence from Asian banks. Journal of Asian Economics, 22(6), pp.460-470. https://doi.org/10.1016/j.asieco.2011.08.003

Termos, A., Naufal, G. and Genc, I. (2013). Remittance outflows and inflation: The case of the GCC countries. Economics Letters, 120(1), pp.45-47 https://doi.org/10.1016/j.econlet.2013.03.037

World Bank. (2012). Benchmarking Financial Systems around the World. Policy Research Working Paper 6175, By Martin Cihak, Ash Demirguc-Kunt, Erik Feyen and Ross Levine; The World Bank

World Bank. (2016). Global financial development report - Financial depth. Retrieved from: http://www.worldbank.org/en/ publication/gfdr/gfdr2016/background/financial-depth

Received on 05-05-2020

Accepted on 11-06-2020

Published on 09-11-2020

DOI: https://doi.org/10.6000/1929-7092.2020.09.40

(C) 2020 Ngonyama et al.; Licensee Lifescience Global.

This is an open access article licensed under the terms of the Creative Commons Attribution Non-Commercial License (http://creativecommons.org/licenses/by-nc/3.0/) which permits unrestricted, non-commercial use, distribution and reproduction in any medium, provided the work is properly cited. 